\title{
RELASI ANTARETNIS DI KAMPUNG ARAB (Studi Komunikasi Antarbudaya di Kelurahan Ampel Surabaya)
}

\author{
Nikmah Suryandari, Andika Trilaksono \\ Prodi Ilmu Komunikasi Fakultas Ilmu Sosial dan Ilmu Budaya Universitas Trunojoyo Madura \\ Email : nikmahsuryandari@gmail.com
}

\begin{abstract}
ABTRACT
This research was conducted in the multi-cultural area of Kampung Ampel Semampir Surabaya. This region has long been known as a region with a high diversity of ethnicities, cultures. This type of research is descriptive qualitative with data collection techniques through in-depth interviews, observation and documentation. The results showed that there was intense ethnic inter-relations between the three ethnicities there, namely Arabic, Javanese and Madura. Each ethnic group has different perceptions towards other ethnic groups, both positive and negative. Verbal non-verbal messages also occur in interactions between ethnic groups with a variety of meanings according to their respective cultural backgrounds. This not infrequently causes friction and disagreement between residents in this region
\end{abstract} Keywords: inter ethnic relations, intercultural communication, Ampel

\begin{abstract}
ABSTRAK
Penelitian ini dilakukan di kawasan Kampung Ampel Semampir Surabaya yang multikultur. Wilayah ini sejak lama sudah dikenal sebagai wilayah dengan keragaman etnisitas, budaya yang tinggi. Jenis penelitian adalah deskriptif kualitatif dengan teknik pengumpulan data melalui wawancara mendalam, observasi dan dokumentasi. Hasil penelitian menunjukkan bahwa di wilayah ini terjadi relasi antaretnis yang intens antara tiga etnis disana, yaitu Arab, Jawa dan Madura. Masing-masing etnis memiliki persepsi yang berbeda terhadap etnis lainnya baik yang positif maupun negatif. Pesan verbal nonverbal juga terjadi dalam interaksi antaretnis dengan beragam pemaknaan sesuai dengan latar belakang budaya masing-masing. Hal ini tidak jarang menimbulkan friksi dan pertentangan antarwarga.
\end{abstract}

Kata Kunci : relasi antar etnis, , komunikasi antar budaya, Ampel

\section{PENDAHULUAN}

Indonesia merupakan sebuah negara kepulauanyang dicirikanolehadanyakeragaman budaya. Keragaman tersebut antara lain terlihat dari perbedaan bahasa, etnis (suku bangsa), dan keyakinan agama (Rahardjo,2005:1). Dalam keragaman tersebut dapat menimbulkan konflik. Di Indonesia, konflik antar kelompok yang berasal dari latar belakang budaya yang berbeda sudah berlangsung lama dan beberapa diantara konflik itu tidak hanya dilakukan lewat penyerangan fisik, tetapi sudah mengarah pada tataran prasangka yang paling tinggi, yaitu eksterminasi. (Rahardjo,2005:vi). 
Sebagai negara dengan tingkat keragaman yang tinggi, relasi antar etnis menjadi fenomena biasa dalam kehidupan bermasyrakat di Indonesia. Surabaya, sebagai salah satu kota metropolitan di Indonesia menjadi salah satu wilayah dengan tingkat keragaman yang tinggi. Salah satu wilayah di Surabaya yang memiliki keragaman tinggi ini adalah Kampung Ampel di wilayah Semampir Surabaya. Meskipun kampung ini lebih dikenal sebagai kampung Arab, namun demikian dalam prakteknya ada beragam etnis yang tinggal dan berinteraksi di wilayah ini. Kelompok masyarakat yang mendiami wilayah ini didominasi masyarakat keturunan Arab, disusul masyarakat etnis Madura dan etnis Jawa (Timuran). Keragaman latar belakang etnis ini menjadi salah satu ciri pembeda kampung Ampel ini dibanding kampung atau wilayah lain di Surabaya.

Penelitian di kawasan Ampel ini merupakan penelitian deskriptif kualitatif yang diharapkan mampu menghasilkan suatu uraian mendalam tentang ucapan, tulisan dan tingkah laku yang dapat diamati dari suatu individu, kelompok, masyarakat, orgamnisasi tertentu dalam suatu konteks yang dapat dikaji dari sudut pandang yang utuh, komprehensif dan holistik atau menyeluruh. (Ruslan,2003:213). Metode dalam penelitian ini adalah kualitatif yang bertujuan menggali atau mebangun suatu proposisi atau menjelaskan makna dibalik realita. Dalam penelitian ini, peneliti berpijak pada realita atau peristiwa yang berlangsung di lapangan. Apa yang dihadapi dalam penelitian adalah dunia sosial sehari-hari. Penelitian ini berupaya memandang apa yang sedang terjadi dalam dunia tersebut dan melekatkan dengan temuan-temuan yang diperoleh didalamnya.
Oleh karena itu apa yang dilakukan oleh peneliti selama dilapangan termasuk dalam suatu posisi yang berdasar kasus atau odeografis yang mengarahkan perhatian pada spesifikasi kasuskasus tertentu (Bungin,2001:124).

Penelitian menggunakan purposive snowballing sampling. Pertama yang dilakukan adalah mencari informan yang diarahkan menjadi tiga typical group yang terdiri atas etnis Arab, etnis Madura dan etnis Jawa. Setelah mendapatkan informan, peneliti menggunakan teknik snowballing untuk mendapat informan lainnya. Teknik snowballing pengambilan secara berantai dengan meminta informasi yang mendukung untuk diwawancarai dan dihubungi terlebih dahulu, demikian seterusnya sampai peneliti menemukan informasi yang sesuai dengan apa yang diteliti (Bungin:2005,13).

Data primer diperoleh wawancara dengan informan yang telah ditentukan yaitu masyarakat kawasan Ampel dari etnis Arab, Madura dan Jawa. Data sekunder diperoleh dari buku, jurnal, kamus, majalah, internet dan media lain yang berkaitan dengan data penelitian. Teknik pengumpulan data melalui wawancara, observasi dan dokumentasi. Analisa data yang digunakan di dalam penelitian ini berdasarkan metode penelitian, yaitu analisa kualitatif, yaitu metode penelitian yang memiliki fokus kompleks, luas dan bersifat subjektif menyeluruh.

Kawasan Ampel merupakan salah satu wilayah dengan tingkat multikultur, dengan beragam etnis, agama, ras dan alirannya (SARA) (Oase:6). Mayoritas masyarakat Ampel adalah etnis Arab, disusul etnis Madura dan Jawa. Sebagian besar masyarakat Ampel bekerja 
sebagai pedagang. Komposisi masyarakat majemuk seperti itu sangat rawan dengan konflik. Dalam observasi awal ditemukan fakta bahwa dalam menyikapi perbedaan tersebut, masyarakat Ampel menjunjung tinggi kerukunan dan prinsip keberagaman di sekitar mereka. Relasi atau komunikasi antar etnis terjadi dengan damai dan kondusif. Apabila terdapat perbedaan dan konflik antara individu maupun konflik, maka hal tersebut tidak sampai meluas dan hanya berkisar pada individuindividu yang terlibat konflik. Kawasan Ampel dalam sejarahnya justru sangat menghargai perbedaan dan keragaman. Berdasarkan faktafakta mengenai keragaman etnis di kawasan Ampel, dapat dikaji mengenai bagaimana relasi antar etnis yang terjadi di wilayah tersebut.

Berinteraksi atau berkomunikasi dengan orang-orang berbeda kebudayaan merupakan pengalaman baru yang selalu dihadapi (Liliweri, 2003: 5). Pengalaman tersebut dapat menimbulkan terjadinya komunikasi antarbudaya. Komunikasi antarbudaya sendiri lebih menekankan pada aspek utama yakni komunikasi antarpribadi diantara komunikator dan komunikan yang kebudayaaannya berbeda (Mulyana,1990:15). Kawasan Ampel oleh masyarakat Surabaya maupun orang luar lebih dikenal sebagai kampung Arab. Kampung Arab Ampel selama ini telah menjadi identitas warga Arab Surabaya dan menjadi jembatan penghubung antara budaya Islam dan budaya modern. Dalam sejarahnya Ampel dikenal sebagai lokasi yang dikenal kental dengan nuansa timur tengah. Perpaduan antara budaya tersebut nampak pada lorong-lorong di kampung ini. Kegiatan perdagangan, tawar menawar antara pedagang dan pembeli menjadi pemandangan sehari-hari yang menggambarkan relasi antaretnis disini. Sebagian besar pedagang di wilayah ini adalah masyarakat etnis Arab, meskipun ada juga pedagang etnis Madura dan Jawa.

Untuk memahami interaksi dalam komunikasi antarbudaya terlebih dahulu harus memahami yang terjadi selama proses komunikasi berlangsung. Untuk memenuhi kebutuhan berinteraksi dengan orang lain yang beragam budaya, diperlukan pemahaman mengenai latar belakang budaya serta kebiasaan dari masingmasing kelompok masyarakat yanag berbeda tersebut. Hal ini dilakukan untuk menghindari kesalahpahaman budaya.

Dalam masyarakat yang terbagi ke dalam kelompok-kelompok berdasarkan identitas kultural akan sulit mencapai keterpaduan sosial (social cohesion), sebab masing-masing kelompok berada dalam lingkup pergaulan yang eksklusif sehingga relatif tidak intensif dalam melakukan komunikasi (atarbudaya) yang efektif yaitu komunikasi yang dimaksudkan untuk mengurangi kesalah pahaman budaya, tetapi justru cenderung melakukan penghindaran komunikasi (communication avoidance) (Rahardjo, 2005: 2).

\section{Komunikasi Antarbudaya}

Komunikasi dan budaya memiliki hubungan timbal balik seperti dua sisi mata uang. Budaya menjadi bagian dari perilaku komunikasi dan pada gilirannya komunikasi akan memelihara, mengembangkan atau mewariskan budaya. Hal ini seperti yang dikatakan oleh Edward T Hall bahwa komunikasi adalah budaya dan budaya adalah komunikasi. 
Komunikasi antar budaya merujuk pada kejadian atau fenomena komunikasi yang terjadi antar partisipan yang memiliki latar belakang budaya yang berbeda. Partisipan komunikasi antar budaya ini menjalin kontak baik secara langsung maupun tidak langsung.

Menurut Stella Ting Toomey (1999) komunikasi antar budaya merupakan proses pertukaran simbolik dimana orang dari dua atau lebih komunitas kultural yang berbeda menegosiasikan makna yang dipertukarkan dalam sebuah jalinan yang interaktif. Adapun Gudykunst \& Young Yun Kim (1997) berpendapat bahwa komunikasi antar budaya merupakan proses transaksional, proses simbolik yang melibatkan atribusi makna antara individu-individu dari kultur yang berbeda.

Komunikasi antarbudaya terjadi ketika dua atau lebih orang dengan latar belakang budaya yang berbeda berinteraksi. Proses ini jarang berjalan dengan lancar dan tanpa masalah. Dalam kebanyakan situasi, para pelaku interaksi antarbudaya tidak menggunakan bahasa yang sama, tetapi bahasa dapat dipelajari dan masalah komunikasi yang lebih besar terjadi dalam area baik verbal maupun nonverbal. Khususnya, komunikasi nonverbal sangat rumit, multidimensional, dan biasanya merupakan proses yang spontan.

\section{Pengalaman Lintas Budaya}

Menurut Schutz (Deddy Mulyana 2005: 178) setiap orang memiliki suatu sistem pengetahuan dari budayanya berupa realitas yang tidak pernah dipersoalkan lagi. Realitas ini menyediakan skema interpretatif bagi seseorang untuk menafsirkan tindakannya dan tindakan orang lain. Sistem makna kultural antar lain merupakan aturan budaya (cultures rules ) dan tema sosial (social themes).

Aturan dan nilai nilai juga dipegaruhi oleh budaya. Budaya yang berbeda menetapkan aturan yang berbeda untuk mencapai hal yang sama. Begitu juga makna dari peristiwa yang sama. Sebagai konsekuensi dari hal ini adalah tindakan yang sama dinilai secara berbeda pula. Hal ini akan memberikan pengalaman lintas budaya yang maenarik bagi masing-masing individu pelaku komunikasi antar budaya.

Latar belakang kebudayaan dari suatu kelompok atau dari seorang individu akan mempengaruhi bagaimana kelompok atau individu itu menyampaikan simbol atau lambang yang berisi pesan ketika mereka melakukan interaksi sosial di dalam kelompok itu atau dengan masyarakat sekitarnya. Interaksi sosial yang terjadi di dalam suatu kelompok atau dengan masyarakat lainnya, menjadi sarana pokok bagi masyarakat itu untuk menafsirkan peristiwaperistiwa sehari-hari dan menggunakannya sebagai sumber kegiatan. Bahasa menjadi sarana untuk mensosialisasikan, sehingga percakapan yang terjadi diantara individu yang ada di dalam kelompok tersebut maupun dengan masyarakat di sekitarnya tidak terpisah dari interaksi sosial, kebudayaan, dan kepribadian (Berman 2001:1)

\section{PEMBAHASAN}

\section{Gambaran Umum Kawasan Kampung Ampel}

Kawasan Ampel berada di Kecamatan Semampir salah satu kecamatan di Kota Surabaya. Semampir adalah kawasan di Surabaya yang penduduknya mayoritas adalah warga 
urban dari Madura. Tingkat kemiskinan di kecamatan ini adalah yang tertinggi di Surabaya. Data dari Kecamatan menyebutkan bahwa ada 15.675 kepala keluarga (KK) yang terkategorikan sebagai keluarga miskin, dengan penyumbang terbesar dari Kelurahan Wonokusumo (4.702 KK) dan Ujung (5.486KK) (Data Monograf Kelurahan Ampel, 2009:13).

Wilayah Kelurahan Ampel berbatasan dengan kelurahan Ujung di sebelah utara, Kelurahan Nyamplungan di sebelah barat dan selatan, Kelurahan Sidotopo di sebalah timur. Komunitas Kawasan Ampel merupakan gabungan dan percampuran beragam suku bangsa yang membentuk keunikan tersendiri. Warga kawasan Ampel memiliki beragam profesi sebagai mata pencahariannya, seperti pedagang, dokter, karyawan, pemuka agama (ustadz). Di wilayah Ampel ini terdapat Masjid Ampel yang menjadi salah satu tujuan wisata religi bagi umat Islam dari seluruh wilayah Indonesia. Berdasarkan sejarahnya, Kawasan Ampel terbentuk saat penyebaran ajaran Islam yang dilakukan oleh Sunan Ampel.

Masyarakat yang bermukim di Kawasan Ampel masih kental mempertahankan karakteristik dan tradisi yang tercermin dalam kehidupan sehari-hari antar etnis. Misalnya etnis Arab (yang identik dengan Kampung Ampel) masih mempertahankan budaya Arab seperti musik-musik Arab, kegiatan keagamaan seperti pengajian di kalangan mereka.

\section{Komunikasi Antarbudaya dalam Beragam Situasi perbedaan}

Ada beberapa prinsip untuk memahami komunikasi antarbudaya diantaranya adalah bahasa, interaksi awal, kesadaran diri, kesadaran membuka diri. Hal ini juga nampak dalam kehidupan antaretnis yang terjadi di kawasan Ampel. Keragaman di kawasan ini tidak jarang menimbulkan masalah atau hambatan. Menurut penuturan $\mathrm{H}$ (Informan 3) salah satu faktor pemicu masalah adalah persaingan usaha, seperti penuturan berikut:

\section{"biasanya di sini terjadi karena rebutan pelanggan, sehingga persaingan kadang terjadi secara tidak sehat"}

Hal ini terjadi karena salah satu pihak kurang menghargai perbedaan dan melakukan praktek dagang yang tidak sehat.

Salah satu perbedaan yang terjadi dalam konteks komunikasi antaretnis di kawasan Ampel ini adalah bahasa. Penggunaan bahasa yang beragam di wilayah ini lebih karena faktor kebiasaan dan tujuan kemudahan bertransaksi dagang. Pedagang etnis Arab mampu memahami bahasa Madura yang sering digunakan oleh pedagang etnis Madura. Hal ini menjadikan transaksi perdagangan berjalan lancar tanpa kendala bahasa. Hal ini diperkuat pernyataan A (Informan 2, etnis Madura) berikut:

"disini, berkomunikasi dengan etnis lain. seperti orang Madura, saya ngerti omongan mereka. Kan berdagang sudah lama, jadi ya.

Sudah tahu maksud bahasa mereka"

Hal serupa juga diungkapkan oleh Informan 3 yang dalam pemikirannya merasa bahwa dalam hubungan antaretnis perlu saling menghormati dan mengingatkan untuk menjaga dari perselisihan, pertengkaran, atau pertikaian lahan maupun lapak dagangan.

"dalam membina hubungan, baik sesama 
etnis maupun antaretnis dalam hal berdagang, harus ada timbal baliknya, saling mengingatkan agar tidak ada kecemburuan sosial, pertengkaran dalam perdagangan”.

\section{Persepsi Antaretnis Di Kawasan Ampel}

Berdasarkan data observasi di lapangan, komunikasi yang terjadi antaretnis Arab dengan etnis lain di Kawasan Ampel lebih banyak dalam konteks hubungan praktek bisnis, perdagangan dan bersifat informatif saja. Sedangkan dalam kehidupan bertetangga, etnis Arab dikenal kurang dalam interaksi dengan tetangga. Hal ini berbeda dengan etnis Madura dan Jawa yang relatif dekat secara ketetanggaan. Mereka sering terlibat pergaulan dan percakapan dalam kegiatan informal seperti sekedar nongkrong maupun ngobrol atau ngerumpi. Karena etnis Arab cenderung jarang bergaul atau berinteraksi dengan etnis lain, ada pandangan yang mempersepsikan mereka secara negatif, seperti penuturan informan 3 berikut:

"orang Arab sini (kampung Ampel) kebanyakan nafsi-nafsi (sendiri-sendiri)”

Selain persepsi negatif, masyarakat etnis Arab di kawasan Ampel juga mendapatkan penilaian atau persepsi positif dari masyarakat etnis lain. Pandangan bahwa etnis Arab memiliki kepribadian yang baik, orang Arab memberi lapangan kerja untuk orang Madura mulai dari berdagang, menjadi pekerja rumah tangga dan pekerjaan lainnya.

Dalam penelitian ini, ada juga persepsi negatif mengenai kelompok etnis lain yang berada di Kawasan Ampel. Persepsi negatif terhadap etnis Madura yang sering muncul diantaranya adalah tinggi nada bicaranya, merasa lebih hebat dari yang lain, seperti kutipan wawancara dengan informan 4 berikut:

"menurut saya orang Madura disini kurang bisa menghargai yang ada di sekelilingnya, suka minta-minta, ada juga yang suka ambil barang orang, apa yang mereka kerjakan pokoknya baik buat mereka, tanpa memikirkan orang lain"

Warga etnis Arab dipersepsikan sebagai orang yang bersifat terbuka hanya dengan orang yang mereka kenal baik. Masyarakat etnis Arab terkesan tertutup dengan orang yang baru dikenal, kurang terbuka, sehingga mereka dipersepsikan sulit bergaul jika dibandingkan dengan etnis lain. Hal ini diperkuat pernyataan Informan 7 dan Informan 8 berikut :

"Saya pernah data warga RT 4 tentang jentik nyamuk, saya datang ke rumahnya, malah dikira minta sumbangan. Padahal saya mau mendata, yang keluar malah pembantunya, kita harus ngotot. Tapi kalau ada perlunya minta ke RT semaunya".

"Orang luar susah mas bicara sama mereka secara langsung sama orang Arab. Kalau ada sales masuk sini susah menawarkan barang, komunikasinya lewat ibu-ibu PKK.

Orang Arab ga mau diijadikan ketua RT".

Untuk warga etnis Jawa dipersepsikan baik dan memiliki kecakapan komunikasi. Hal ini tergambar dari salah satu warga kawasan Ampel beretnis jawa, yaitu Ibu Ima. Ibu Ima dianggap memiliki kemampuan berkomunikasi yang baik dan dapat bergaul dengan seluruh warga kawasan Ampel. Dengan kemampuannya ini, Ibu Ima dipercaya menjadi Ketua RT 4. 
Berikut penuturan Informan 7 :

"saya sering dijadikan tempat curhat warga sini, tempat bertanya dan minta pertimbangan kalau ada masalah"

Selain dipersepsikan baik, etnis Jawa dipersepsikan sebagai orang yang halus, mudah diatur, sopan dan ramah. Orang Jawa di kawasan Ampel dikenal diam dan dalam bergaul tidak memilih teman. Hal ini diperkuat pernyataan informan 1 berikut:

"kalau orang Jawa disini mudah diatur, seperti bayar iuran pedagang, tidak seperti orang Madura, dikenal alot"

\section{Pesan Verbal Dan Nonverbal Dalam Komunikasi Antaretnis Di Kawasan Ampel}

Bentuk paling umum dari pesan verbal manusia adalah bahasa yang terucapkan. Bahasa yang terucap terdiri atas simbol-simbol dan suara yang dapat mewakili bernda, perasaan maupun gagasan. Dalam komunikasi setidaknya ada dua orang yang saling mengirimkan lambanglambang tersebut yang bisa bersifat verbal berupa kata-kata atau bersifat nonverbal berupa ekspresi, atau ungkapan tertentu dan gerakan tubuh (Johnson dalam Supratiknya,1995:30).

Dalam komunikasi nonverbal yang ditunjukkan oleh etnis Madura terletak pada penekanan dalam berkomunikasi dengan etnis lain, misalnya berbicara dengan nada yang tinggi dan suara yang lebih keras. Dalam penelitian ini, ada kegiatan komunikasi nonverbal melalui gerakan tubuh (gesture) terbagi menjadi 3 komponen yaitu pesan fasial, gestural dan postural. Pesan nonverbal para informan penelitian terlihat berbeda pada masing-masing etnis. Pada informan 1, 3, 7, 8 mereka memiliki pembawaan yang terbuka baik dengan sesama etnis maupun yang berbeda etnis. Sedangkan informan 5 lebih tertutup, dan sering bersikap ragu. Etnis Arab dalam penelitian ini cenderung lebih tertutup dan sulit berinteraksi dengan orang yang baru mereka kenal. Pesan nonverbal yang muncul dalam innteraksi pada etnis Madura adalah nada suara yang tinggi saat berbicara. Dalam kondisi tertentu pesan nonverbal ini dapat dimaknai sebagai bentuk kemarahan.

Dalam komunikasi nonverbal juga ditunjukkan pesan postural, salah satunya dengan immadiecy yaitu ungkapan suka atau tidak suka terhadap individu yang lain. Hal ini ditunjukkan oleh pedagang di Ampel dengan cara tidak menyapa apabila mereka bertengkar. Pesan nonverbal yang ditunjukkan oleh etnis Arab adalah dengan tidak menyapa atau bersikap acuh, cuek pada orang lain yang tidak disukai. Sedangkan pada etnis Madura, pesan nonverbal lebih sering nampak pada nada suara yang tinggi saat berbicara.

Pesan verbal dan nonverbal yang disampaikan mengandung makna tertentu tentang perasaan individu melalui pesan fasial dan postural. Pesan fasial adalah pesan yang mengandung makna, seperti kebahagiaan, terkejut, ketakutan dan sebagainya. Pesan postural berhubungan dengan rasa suka atau tidak suka terhadap individu lain, status yang tinggi dan reaksi emosional terhadap lingkungan. Berikut adalah contoh bentuk pesan fasial berupa kemarahan ditunjukkan Informan 5 :

"Ya umpatan-umpatan sering saya dengar, seperti "ooh dasar Arab"” 
Saat mengucapkan kalimat tersebut, Informan 5 nampak menahan perasaan yang menunjukkan bahwa dia sedang marah karena diejek dengan sebutan "dasar Arab".

Pesan nonverbal juga bermakna kecemasan, ketakutan, kekhawatiran juga muncul pada interaksi antara etnis Jawa dan Madura. Kecemasan, ketakutan, kekhawatiran muncul karena nada ancaman untuk menyingkirkan barang dagangannya bila mereka tidak segera membayar iuran. Ancaman muncul dari preman etnis Madura kepada pedagang etnis Jawa.

\section{KESIMPULAN}

Kampung Ampel adalah salah satu wilayah di Surabaya yang merepresentasikan keragaman etnis, yaitu etnis Arab, madura dan Jawa. Di kawasan ini terjadi komunikasi antarbudaya yang melibatkan ketiga etnis tersebut secara intens. Interaksi yang terjadi lebih banyak dalam bidang perdagangan. Dalam interaksi antar etnis di wilayah ini ada banyak persepsi baik negatif maupun positif dari masing-masing etnis. Pesan verbal nonverbal juga terjadi dalam interaksi masyarakat multikultur disini.

\section{Saran}

Dalam masyarakat multikultur, keragaman etnis, budaya dan karakter lainnya hendaknya tidak untuk dipertentangkan, namun menjadi perekat dalam interaksi sosial yang saling menguntungkan. Dengan melihat hasil dari penelitian ini, ada penelitian lanjutan yang dapat dilakukan dengan tema serupa namun dilakukan di wilayah multikultur yang lain. Penelitian dapat dilakukan dengan teori maupun pendekatan yang berbeda, dengan instrumen yang lebih bervariasi.

\section{DAFTAR PUSTAKA}

Bungin, Burhan. 2008. Analisis Data Kualitatif. Bandung. PT Raja Grafindo Persada

Devito, J.A. 1997. Komunikasi Antar Manusia. Eds. 5. Jakarta: Professional Book

Effendi, Onong. 1993. Ilmu, Teori dan Filsafat Komunikasi. Bandung: PT. Citra Aditya Bakti.

Effendy, Onong Uchjana. 2003. Ilmu komunikasi teori dan praktek. Bandung: PT Remaja Rosdakarya

Kriyantono, R. 2007. Teknik Praktis Riset Komunikasi: Disertai Contoh Praktis Riset Media, Public Relations, Advertizing, Komunikasi Organisasi, Komunikasi Pemasaran. Jakarta: Kencana

Mulyana, Deddy. 2014. Ilmu Komunikasi: Suatu Pengantar. Cetakan ke 18. Bandung: PT. Remaja Rosdakarya.

Deddy Mulyana dan Jalaluddin Rakhmat. 2006. Komunikasi Antarbudaya: Panduan Berkomunikasi dengan Orang-Orang Berbeda Budaya. Bandung: Remaja Rosdakarya.

Pawito. 2007. Penelitian komunikasi kualitatif. Lembaga Kajian Islam dan Sosial (LKIS) : Yogyakarta

Salim. Agus. 2006. Stratifikasi Etnik : Kajian Mikro Sosiologi Interaksi Etnis Jawa Dan Cina. PT Tiara Wacana : Yogyakarta 